\author{
MOHAMED ELIMEM ${ }^{\mathrm{a}}$ - CHAIMA LAHFEF ${ }^{\mathrm{ab}}$ - MAHA KALBOUSSI ${ }^{\mathrm{a}}$ - ANIS SAKHRAOUI ${ }^{\mathrm{ac}}$ - BALKIS \\ BESSOUDA $^{\text {a }}$ - ESSIA LIMEM SELLEMI ${ }^{\text {-SSLIM ROUZ }}{ }^{\text {a }}$
}

\title{
THE ALIEN PSYLLID MACROHOMOTOMA GLADIATA KUWAYAMA, 1908 (HEMIPTERA PSYLLOIDEA HOMOTOMIDAE): SPREAD AND DAMAGE OF A RECENTLY RECORDED PEST OF FICUS MICROCARPA TREES IN TUNISIA $^{(1)}$
}

\author{
a - Research Laboratory of Agricultural Production Systems and Sustainable Development LR03AGR02, Depart- \\ ment of Agricultural Production, Higher School of Agriculture of Mograne (ESAM), Mograne, 1121, Zag- \\ houane, University of Carthage, Tunisia. \\ $b^{b}$ - National Agronomy Institute - Tunis, Carthage University, 1082 -Tunis- Mahrajène, Tunisia. \\ ${ }^{c}$ - Agricultural Higher School of Kef, Jendouba University, 7119 Le Kef-Tunisia. \\ ${ }^{d}$ - General Directorate of Agricultural Protection, Ministry of Agriculture of Water Resources and Fisheries, 30, \\ Alain Savary Street, 1002-Tunis le Belvedere, Tunisia. \\ Corresponding Author: Mohamed Elimem; e-mail: mohammed.elimem123@gmail.com; \\ ORCID: https://orcid.org/0000-0001-7413-5539
}

\begin{abstract}
(1) Parts played by the different Authors: Elimem M. recorded the unusual symptoms of Macrohomotoma gladiata, collected samples and identified the species. Lahfef C. and Kalboussi M. examined the samples in the laboratory, as well as dissected and mounted the specimens on slide. Sampling in governorates of Tunis and Ariana was accomplished by Elimem M., Sakhraoui A., Bessouda B., Limem Sellemi E., and Rouz S.

Elimem M., Lahfef C., Kalboussi M., Sakhraoui A., Bessouda B., Limem Sellemi E., Rouz S. - The alien psyllid Macrohomotoma gladiata Kuwayama (1908) (Hemiptera Psylloidea Homotomidae); a new pest on Ficus microcarpa trees in Tunisia.

During an inventory study of Psylloidea species carried out in Tunisia, the alien psyllid, Macrohomotoma gladiata Kuwayama, 1908 (Hemiptera Psylloidea Homotomidae), recently recorded in the country, has been detected on ornamental Ficus microcarpa, in public and private parks and gardens in many locations of the urban areas of the governorates of Tunis and Ariana, showing a fast spread in the area. This psyllid species has been observed causing damages and vegetative disorders to Ficus trees, especially white wax secretion, leaf wrapping and honeydew excretion on leaves and twigs. The number of infested trees increased from our first observations in late 2020 to early 2021. An Anthocoris sp. (Hemiptera Anthocoridae) has been observed to naturally prey on M. gladiata in many investigated locations.
\end{abstract}

KEY WoRDS: Macrohomotoma gladiata, Ficus microcarpa, predator, Tunisia, preliminary monitoring

\section{INTRODUCTION}

Psylloidea is a highly diversified superfamily of Hemiptera Sternorrhyncha, which includes a number of species ranking between 3000 and 4000, according to the authors (MIFSUD et al., 2010; MARTONI and BROWN, 2018; OUVRARD, 2021). This insect group is very old and dates back from the late upper Cretaceous to early Eocene (OUVRARD et al., 2013). Some species are used as biological control agents of plants; this is the case, for example, of Arytainilla spartiophila (Foerster) which is highly host specific on Cytisus scoparius (L.) Link (SYRETT et al., 2007). A high number of psyllids are known as pests of many plants and are able to cause great economic losses (MARTONI and BROWN, 2018). Most psyllids are monophagous or oligophagous, with very few polyphagous species known worldwide (Ouvrard et al., 2015). Most species are responsible for different kind of damages to their host plants (EL NASR and ABD-RABOU, 2012). Many of them cause crop diseases since they are vectors of bacteria, such as Diaphorina citri Kuwayama, causing citrus greening or huanglongbing which is associated to Candidatus Liberibactrer asiaticum Jagoueix et al., Candidatus L. africanus Jagoueix et al. and Candidatus L. americanus Teixeira et al. (NAVA et al., 2007), or Bactericera trigonica Hodkinson and B. nigricornis Foerster, vectors of Candidatus Liberibacter solanacearum Liefting et al. on Apiaceae (BEN OTHMEN et al., 2019). Some psyllids build a protective covering made by white waxy secretions on leaves and twigs of their host plants and produce a large amount of honeydew on which epiphytic fungal species may develop, giving a black dirty appearance to leaves and affecting photosynthesis (EL NASR and ABD-RABOU, 2012; RADONJIC and HRNCIC, 2017).

Within the superfamily Psylloidea, the genus Macrohomotoma Kuwayama (family Homotomidae) originates from the Indo-Australian region and presently includes 15 species developing on Ficus spp. trees (HoLlis and BROOMFIELD, 1989; OUVRARD, 2021). Macrohomotoma gladiata Kuwayama, 1908, is an oligophagous psyllid that attacks various Ficus species (MIFSUD and PORCELLI, 2012; RADONJIC and HRNCIC, 2017). Main host of M. gladiata is Ficus retusa L. (HoLLIS and BROOMFIELD, 1989). However, other Ficus species may be attacked, such as Ficus benghalensis L., F. cuspidatocaudata Hayata, F. macrophylla Desf. ex Pers., Ficus microcarpa L.f., F. religiosa L. (BELLA and RAPISARDA, 2014; EPPO, 2016; OUVRARD, 2021). 
According to OUVRARD (2021), M. gladiata is of Asian origin. It has been reported in Asia in many countries such as China (HODKINSON, 1986), India (HAYAT and KHAN, 2014), Indonesia (CRAWFORD, 1928), Taiwan (YANG et al., 2009), Japan and Malaysia (BURCKHARDT et al., 2018). The first occurrence of this psyllid in the EPPO region has been reported in Spain (MIFSUD and PORCELLI, 2012; SANCHEZ, 2012). Then it has been reported in other European countries such as Malta (MIFSUD et al., 2012), Italy (PEDATA et al., 2012; BELLA and RAPISARDA, 2014; EPPO, 2016), France (ROBERTI et al., 2016), Montenegro (RADONJIC and HRNCIC, 2017), Cyprus (COMPTON et al., 2020), Gibraltar (MALUMPHY and GUILLEM 2020), Greece (MALUMPHY and GUILLEM, 2020) and Portugal (BELLA and AgUIAR, 2020). This species has been reported in the USA in California as new to North America (RUNG, 2016). In Africa, M. gladiata has been registered till now only in Algeria (GUENAOUI and OUVRARD, 2016) and Morocco (MALUMPHY and GUILLEM, 2020) and very recently it has been recorded also in Tunisia (HARBI et al., 2021).

Following its mentioned first detection in the country, this paper provides additional information on the spread and distribution of M. gladiata on Ficus trees in Tunisia, giving also data resulting from a monitoring of its natural predator detected in these newly invaded areas.

\section{NEW FINDINGS AND SPREAD OF MACROHOMO- TOMA GLADIATA IN TUNISIA}

In the first record of $M$. gladiata in Tunisia (HARBI et al., 2021), the presence of this insect is reported only for the urban area of the Belvedere Park, in Tunis, where it has been noted in September 2020. Additional and progressively increasing findings of the psyllid are reported in the present paper, showing its fast spread in the country.

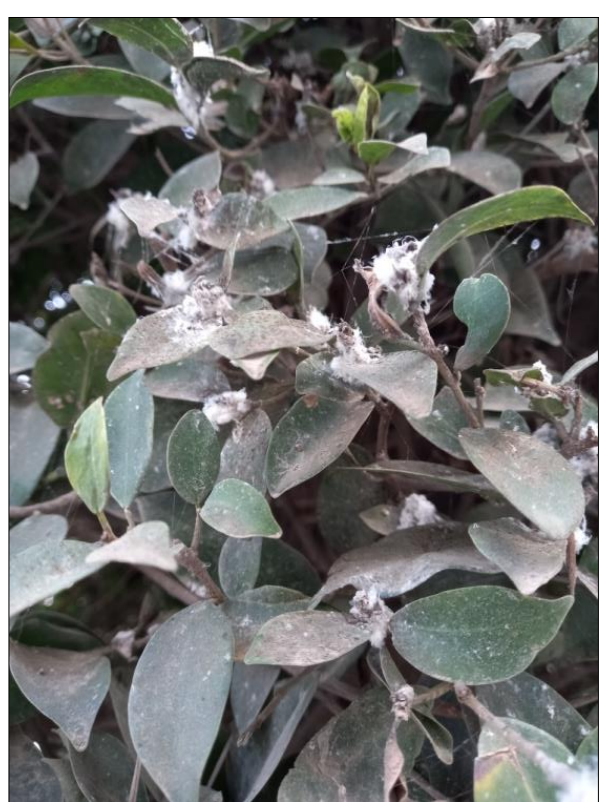

Fig. I - Leaves and twigs of Ficus microcarpa covered by white waxy secretions and honeydew with dirty black appearance caused by fungi.
In particular, in October $03^{\text {rd }} 2020$, the first author noted unusual symptoms on Ficus microcarpa trees, with numerous leaves and twigs (especially new ones) covered by white waxy secretions and honeydew (Fig. I). Infested trees were located in an area along a main street and in a public park (4 and 3 trees, respectively) in SidiBousaid (Tunis governorate, Tunisia). Twigs were collected, placed in plastic bags and transferred to the laboratory of Entomology at the Higher School of Agriculture of Mograne, where all developing stages of the pest were observed (Fig. II, 1, 2, 3). Specimens were preserved in $70 \%$ ethanol, for following dissection, slide mounting and morphological identification. From October $23^{\text {rd }}$ 2020 till April $11^{\text {th }} 2021$, further inspections have been realized in different locations, in order to define the distribution of the insect in the country and monitor the degree of infestation in each area (Fig. III, Table 1).

\section{IDENTIFICATION OF THE NEW PEST}

All samples collected from different investigated sites and at different dates were preliminary observed under a low magnification binocular microscope. Then, selected adults (males and females) were dissected and slide mounted, in order to observe taxonomically important body regions (e.g.: antennae, forewings, male and female genitalia) at a high magnification microscope. Identification, carried out based on the keys reported by MIFSUD and PORCELLI (2012), ROBERTI et al. (2016) and RADONJIC and HRNCIC (2017), leaded to the species Macrohomotoma gladiata Kuwayama, 1908.

According to CRAWFORD (1928), MIFSUD and PORCELLI (2012), ROBERTI et al. (2016) and RADONJIC and HRNCIC (2017), M. gladiata males (Fig. IV, 1) are about 2 to $2.3 \mathrm{~mm}$ and females (Fig. IV, 2) about $3 \mathrm{~mm}$ long. Head as wide as the thorax, strongly down-curved. Vertex about 2.5 times as wide as long. Antennae $10 \mathrm{seg}-$ mented (Fig. IV , 4), thick (segments nearly half as thick as long), not longer than the head width (between eyes), yellowish-brown with last segment darker in color, Thorax, in profile, strongly arched, light to dark brown in color (Fig. IV, 1-2), with yellowish white stripes anterior to the base of forewings but without a dark stripe in the cubital area. Forewings transparent, with distinct and large brown-blackish markings proximal to vein $\mathrm{Cu}_{1 \mathrm{~b}}$ and at apex of pterostigma, as well as with three spots in the radular areas (Fig. IV, 3); veins with no setae. Metatibiae without basal spine; with 4 apical internal spurs. Male genitalia with proctiger much wider than long and with two lobes posteriorly. Aedeagus long, with basal segment twice as long as the apical one (Fig. IV, 5). Female genitalia as in Fig. IV, 6. Nymphs light brown with brown wing pads; apical margin of the abdomen pointed (Fig. IV, 7).

\section{EFFECT ON HOST PLANT AND DAMAGE}

This psyllid negatively affects Ficus species by wrapping their leaves, especially on new growing shoots that will be also covered by abundant white waxy secretion and honeydew produced by the insect (MIFSUD and PORCELLI, 2012; BELLA and RAPISARDA, 2014; ROBERTI $e t$ al., 2016; RADONJIC and HRNCIC, 2017). 


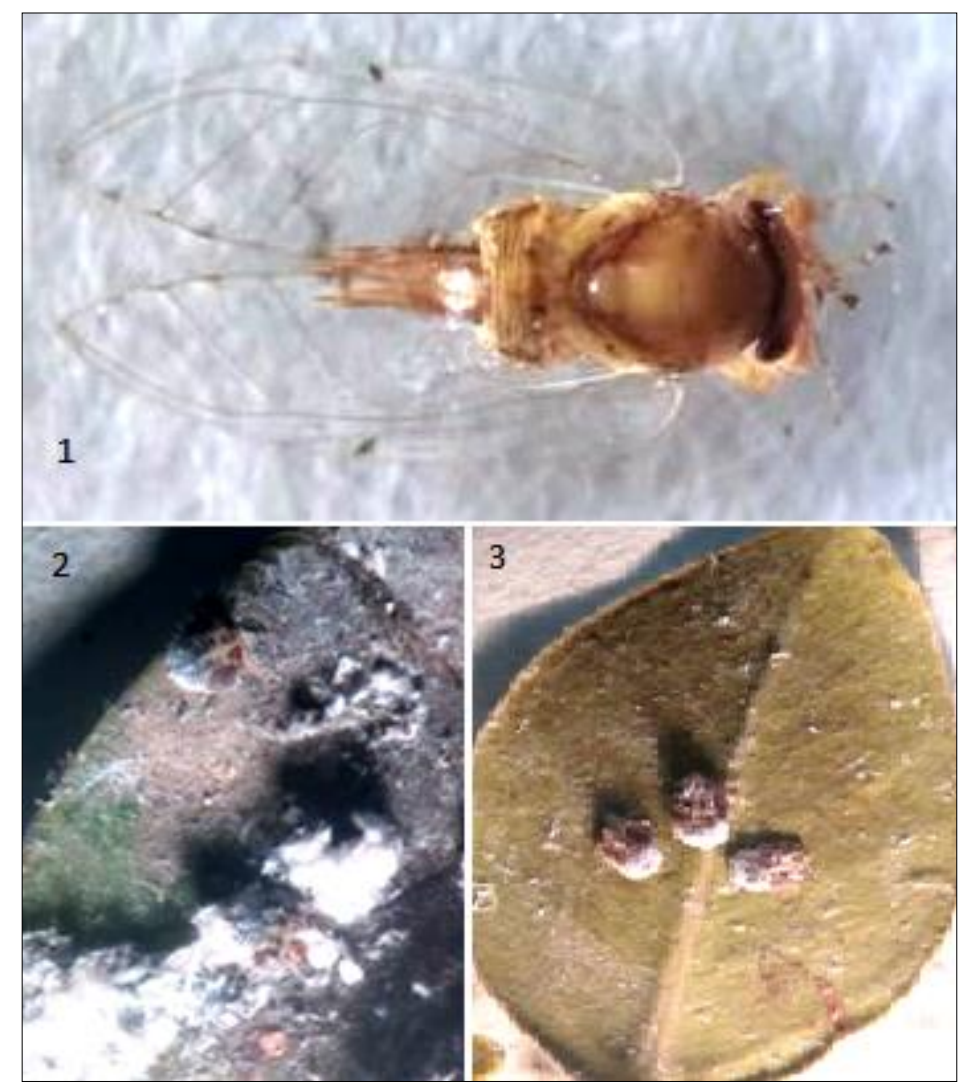

Fig. II - Macrohomotoma gladiata: adult female (1); larva with white waxy secretion (2); larvae on Ficus microcarpa leaf (3).

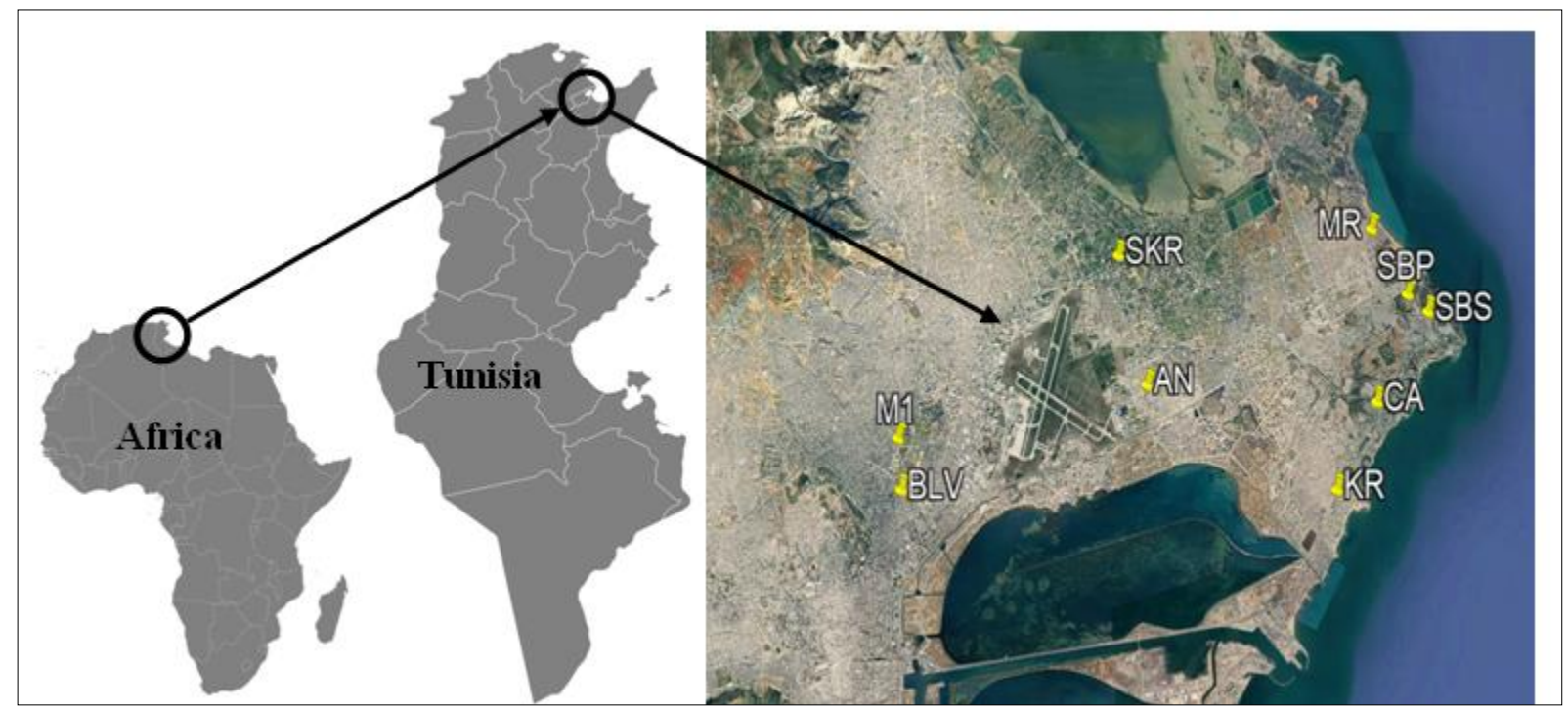

Fig. III - Map of the investigated locations where Macrohomotoma gladiata has been detected (legend: SBS: Sidi-Bousaid Street, SBP: Sidi-Bousaid Park, MR: La Marsa, M1: Menzah 1, BLV: Belvedere; AN: Aouina, SK: La Soukra, KR: Kram, CA: Carthage-Amilcar). 
Table 1 - Geographic localization of different investigated sites where Macrohomotoma gladiata has been detected.

\begin{tabular}{|c|c|c|c|c|c|}
\hline Location & Governorate & $\begin{array}{c}\text { Kind of loca- } \\
\text { tion }\end{array}$ & Abbreviation & $\begin{array}{l}\text { Geographic } \\
\text { localization }\end{array}$ & $\begin{array}{l}\text { Altitude } \\
\text { (m) }\end{array}$ \\
\hline $\begin{array}{l}\text { Sidi-Bou- } \\
\text { said }\end{array}$ & Tunis & Street & SBS & $\begin{array}{l}36^{\circ} 52^{\prime} 27.52^{\prime \prime} \mathrm{N} \\
10^{\circ} 20^{\prime} 06.70^{\prime \prime} \mathrm{E}\end{array}$ & 32 \\
\hline $\begin{array}{l}\text { Sidi-Bou- } \\
\text { said }\end{array}$ & Tunis & Public park & SBP & $\begin{array}{l}36^{\circ} 52^{\prime} 17.01 ” \mathrm{~N} \\
10^{\circ} 20^{\prime} 30.13^{\prime \prime} \mathrm{E}\end{array}$ & 49 \\
\hline La Marsa & Tunis & Street & MR & $\begin{array}{l}36^{\circ} 53^{\prime} 10.05^{\prime \prime} \mathrm{N} \\
10^{\circ} 19^{\prime} 23.30^{\prime \prime} \mathrm{E}\end{array}$ & 14 \\
\hline Menzah 1 & Tunis & Street & M1 & $\begin{array}{l}36^{\circ} 50^{\prime} 13.90^{\prime \prime} \mathrm{N} \\
10^{\circ} 10^{\prime} 55.24 " \mathrm{E}\end{array}$ & 2 \\
\hline Belvedere & Tunis & Street & BLV & $\begin{array}{l}36^{\circ} 49^{\prime} 39.58^{\prime \prime} \mathrm{N} \\
10^{\circ} 11^{\prime} 03.46^{\prime} \mathrm{E}\end{array}$ & 7 \\
\hline Aouina & Tunis & Private garden & AN & $\begin{array}{l}36^{\circ} 51^{\prime} 07.46^{\prime \prime} \mathrm{N} \\
10^{\circ} 15^{\prime} 24.07^{\prime \prime} \mathrm{E}\end{array}$ & 1 \\
\hline La Soukra & Ariana & Street & SK & $\begin{array}{l}36^{\circ} 52^{\prime} 33.15^{\prime \prime} \mathrm{N} \\
10^{\circ} 14^{\prime} 42.22^{\prime \prime} \mathrm{E}\end{array}$ & 4 \\
\hline Kram & Tunis & Street & $\mathrm{KR}$ & $\begin{array}{l}36^{\circ} 50^{\prime} 11.94 ” \mathrm{~N} \\
10^{\circ} 18^{\prime} 59.25^{\prime \prime} \mathrm{E}\end{array}$ & 6 \\
\hline $\begin{array}{l}\text { Carthage- } \\
\text { Amilcar }\end{array}$ & Tunis & Street & $\mathrm{CA}$ & $\begin{array}{l}36^{\circ} 51^{\prime} 12.73 ” \mathrm{~N} \\
10^{\circ} 19^{\prime} 38.31^{\prime \prime} \mathrm{E}\end{array}$ & 12 \\
\hline
\end{tabular}

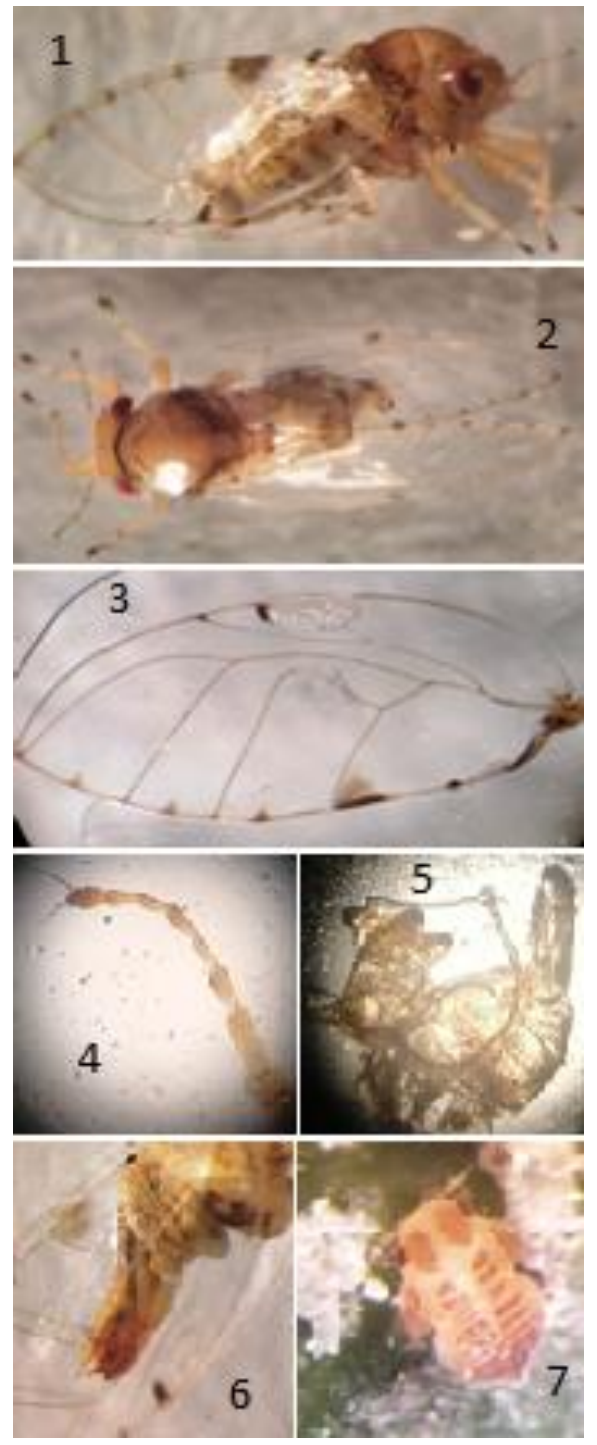

Fig. IV- Macrohomotoma gladiata: adult male with thorax in profile view strongly arched (1); adult female in dorsal view (2); forewing (3); antenna (4); external male genitalia (5); external female genitalia (6); larva with apical margin of abdomen pointed (7).

Deformation of shoots and growth stinting are observed as additional damages to Ficus trees when infestations become important (RADONJIC and HRNCIC, 2017). The strong curled leaves protect nymphs of $M$. gladiata from insecticides and potential antagonists (MIFSUD and PORCELLI, 2012).

During our observations in different Tunisian locations, only $F$. microcarpa was attacked by $M$. gladiata although other Ficus species were growing nearby, such as $F$. elastica, F. macrophylla and $F$. rubiginosa Desf. ex Vent.. However, and according to PEDATA et al. (2012), BELLA and RAPISARDA (2014) and OUVRARD (2021), $F$. macrophylla is among host plants that $M$. gladiata may attack.

As previously stated, attacks by $M$. gladiata were first observed by us in Sidi-Bousaid, in early October 2020, only on totally 7 F. microcarpa trees. Anyway, following monitoring activity performed till mid April 2021 evidenced how the number of infested trees rapidly increased, up to 53 total trees at the end of observations (38 along a main street and 15 in a public park, respectively). Similar increasing in the number of infested trees has been shown also in other investigated locations, especially in La Marsa (MR) with 18 trees on April $11^{\text {th }} 2021$ (Fig. V). Many colonies were observed especially on new shoots of $F$. microcarpa, that were easily detectable by the cottony aspect given by the high amount of white waxy secretions produced by the nymphs on leaves and twigs of the host plant (Fig. II, 3). All immature instars and adults (males and females) were observed hidden un- 
der the white waxy secretions. The contemporary presence of all development stage of the insect indicates that generations overlap. This was reported also by MIFSUD and PORCELli (2012), BELla and RAPISARDA (2014), LABORDA et al. (2015) and RADONJIC and HRNCIC (2017).

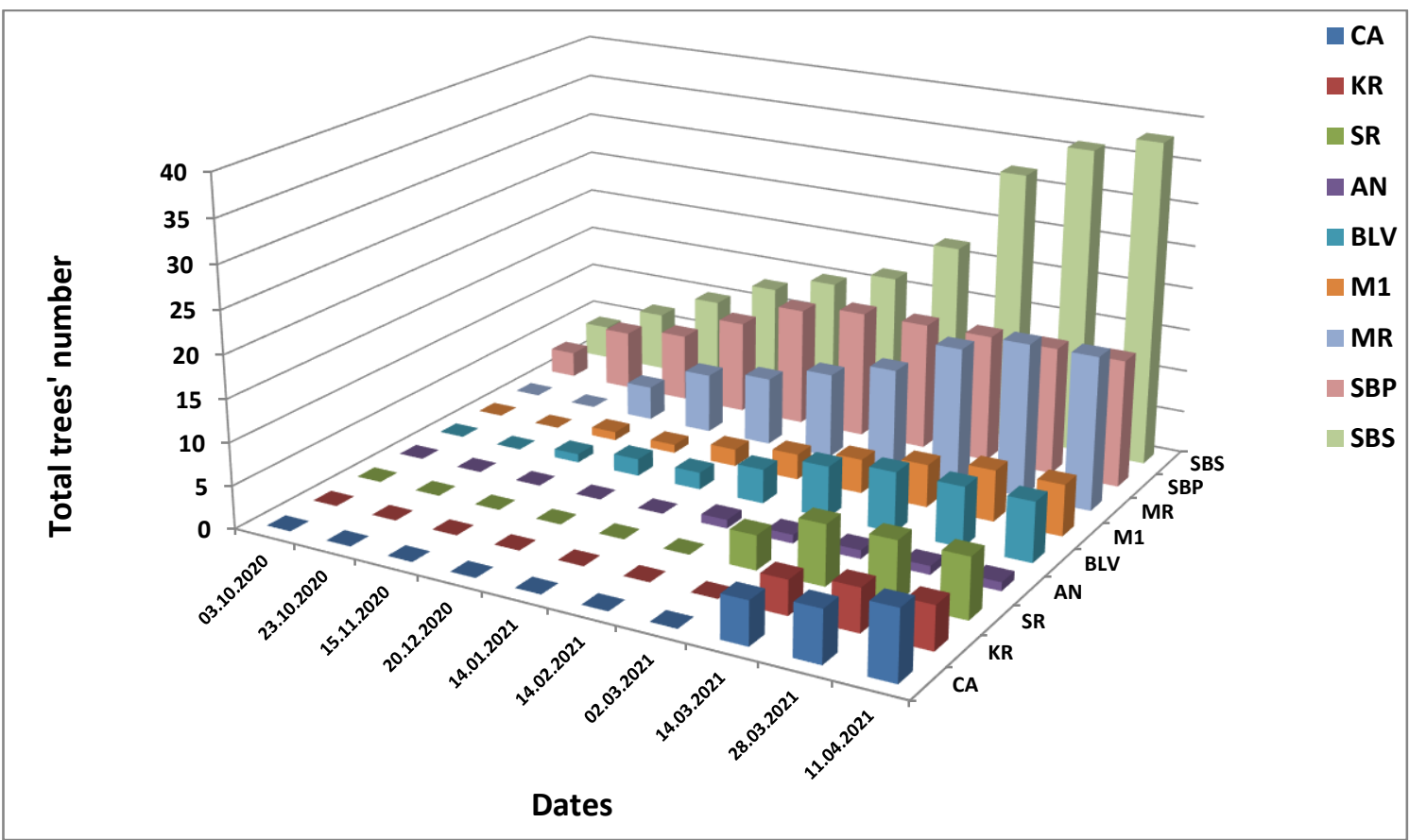

Fig. V. Monitoring of infested trees with Macrohomotoma gladiata populations in different investigated locations (legend: SBS: Sidi-Bousaid Street; SBP: Sidi-Bousaid Public Park; MR: La Marsa; M1: Menzah 1; BLV: Belvedere; AN: Aouina; SR: La Soukra; KR: Kram; CA: Carthage-Amilcar).

According to JiMENEZ-ALAGARDA et al. (2014), populations of $M$. gladiata in Valencia in Spain are very abundant from February to June. This is confirmed by our observations, with infestations becoming important starting from February. As already indicated by ROBERTI $e t$ al. (2016), at our observations and in almost all investigated locations this insect showed to be able of colonizing quickly all trees occurring in a row, with young infested shoots becoming deformed and stopping their development. SANCHEZ (2012) mentioned that this pest species spread rapidly in just some months along the Mediterranean coast of Spain.

\section{NATURAL ENEMIES}

During our monitoring of $M$. gladiata in different investigated locations in Tunisia, natural enemies were observed. Identification according to PÉRICART (1972) leaded to a true bug belonging to the family Anthocoridae and the genus Anthocoris Fallen (1814). This bug was present in five of the nine investigated locations: SBS, SBP, MR, SK and CA (Table 2). This indicates how natural biological control may be established in urban areas and reduce psyllid populations.

Table 2 - Distribution of Anthocoris sp. in different investigated locations

\begin{tabular}{ccccc}
\hline Location & Governorate & $\begin{array}{c}\text { Kind of loca- } \\
\text { tion }\end{array}$ & Abbreviation & Natural enemies \\
\hline Sidi-Bousaid & Tunis & Street & SBS & + \\
Sidi-Bousaid & Tunis & Public park & SBP & + \\
La Marsa & Tunis & Street & MR & + \\
Menzah 1 & Tunis & Street & M1 & - \\
Belvedere & Tunis & Street & BLV & - \\
Aouina & Tunis & Private garden & AN & - \\
La Soukra & Ariana & Street & SK & + \\
Kram & Tunis & Street & KR & - \\
Carthage-Amilcar & Tunis & Street & CA & + \\
\hline
\end{tabular}

Legend: +; presence of Anthocoris, -; absence of Anthocoris. 
The family Anthocoridae contains between 400 and 600 species worldwide; in particular, the genera Orius Wolff and Anthocoris are of great importance in biological control (ELIMEM et al., 2018). According to LABORDA et al. (2015), Anthocoris nemoralis (Fabricius) is among the most abundant predator species that were found feeding on M. gladiata in urban Ficus trees in Valencia (Spain). MIFSUD and PORCELLI (2012) mentioned that predation by Anthocoris sp. may help to control $M$. gladiata and that the effectiveness of this natural biological control agent should be studied.

\section{CONCLUSIVE REMARKS}

The alien psyllid $M$. gladiata is considered as one of the most harmful pests on Ficus trees. It infests young twigs and leaves which will prevent trees, especially young ones, to grow, stop their development and let them die. In addition, in urban areas, the development of white waxy secretions is considered undesirable, since they fall to the ground under attacked trees and can interfere with people. The presence of honeydew makes damages more serious as long as it will attract ants and other pests, such as mealybugs, and allow sooty mold fungi developing, giving a black dirty appearance to plants and affecting their photosynthesis. All mentioned damages (direct and indirect) were observed by us during the investigation here reported, which make adequate control strategies needed in order to prevent diffusion of this pest to other regions of the country.

\section{REFERENCES}

BELLA S., RAPISARDA C., 2014 - New findings in Italy of the recently introduced alien psyllid Macrohomotoma gladiata and additional distributional records of Acizzia jamatonica and Cacopsylla fulguralis (Hemiptera Psylloidea). - Redia, 97: 151-155.

Bella S., AguiAR A.F., 2020 - Non-native insect pests from the Madeira Archipelago (Portugal): new records and further data (Insecter: Orthoptera, Thysanoptera, Hemiptera, Coleoptera, Diptera, Lepidoptera, Hymenoptera). - Fragrnenta entomologica, 52 (2): 369-376.

Ben Othmen S., AbBes K., El IMem M., OuvRard D., RAPISARDA C., CHERMITI B., 2019 - Bactericera trigonica and B. nigricornis (Hemiptera: Psylloidea) in Tunisia as potential vectors of 'Candidatus Liberibacter solanacearum' on Apiaceae. - Oriental Insects, 53 (4): 497-509. https://doi.org/10.1080/00305316. 2018.1536003.

BurCKhardt D., GeOnho C., SEunghwan L., 2018 Moriphila furva gen. and sp. nov. (Hemiptera: Psylloidea: Homotomidae), a new jumping plant-louse from Korea associated with Morus australis (Moraceae). - Zootaxa, 4444(3): 299-315. https://doi.org/ 10.11646/zootaxa.4444.3.5

COMPTON S.G., StAVRINIDES M., KAPONAS C., THOMAS P.J., 2020 - No escape: most insect colonisers of an introduced fig tree in Cyprus come from the plant's native range. - Biological Invasions, 22: 211-216. https://doi.org/10.1007/s10530-019-02132-4

CRAWFORD D.L., 1928 - Fauna sumatrensis (Beitrag Nr. 61). - Psyllidae, 17: 425-426.

ELIMEM M., LIMEM-SELLEMI E., HAFSI A., BEN OTHMEN S., CHERMITI B., 2018 - The genus Orius Wolf (Insecta; Heteroptera; Anthocoridae) in the Tunisian coastal region: biodiversity and distribution. - Journal of new sciences, Sustainable Livestock Management, 5 (2), 91-99.

El NASR A.S., ABD-RABOU S., 2012 - Common pests of psyllids and whiteflies (Hemiptera: Psylloidea: Aleyrodoidea) infesting orchard trees in Egypt. Egyptian Academic Journal of Biological Sciences, 5(3): $147-152$.

EPPO, 2016 - Premiers signalements de Macrohomotoma gladiata en Italie et en Algérie. - OEPP Service d'Information. PARIS, 2016-01. 23 pp.

GUENAOUI Y., OUVRARD D., 2016 - Une nouvelle espèce de psylle découverte sur Ficus en Algérie. - Phytoma, 691: 7-9.

Harbi A., Abbes K., Rapisarda C., Onillon J-C., CHERMiti B., 2021 - Macrohomotoma gladiata $\mathrm{Ku}$ wayama, 1908 (Hemiptera: Psylloidea): A new pest of Ficus microcarpa L.f. in Tunisia. - EPPO Bulletin, 52 (2): 1-5. https://doi.org/10.1111/epp.12751

HAYAT M., KHAN F.R., 2014 - Taxonomic notes on some Indian Encyrtidae (Hymenoptera : Chacidoidea) with description of a new genus and species. - Oriental Insects, 48(1-2): 123-149. http://dx.doi.org/10.1080/ 00305316.2014 .959789

HODKINSON I.D., 1986 - The psyllids (Homoptera: Psylloidea) of the Oriental Zoogeographical Region: an annotated check-list. - Journal of Natural History, 20: 299-357. https://doi.org/10.1080/00222938600770251

HOLLIS D., BROOMFIELD P.S., 1989 - Ficus-feeding psyllids (Homoptera), with special reference to the Homotomidae. - Bulletin British Museum (Natural History), Entomology Series, 58: 131-183.

JiMENEZ-AlagardA C., GALAN-BleSA J., GARCIAPARRA I., LAZARO MJ., LABORDA R., SANCHEZ-DOMingo A., BertomeU A., XAMANi P., RodRigo E., 2014 - Comparación del ciclo biológico de diferentes especies de psilas presentes en árboles ornamentales de la ciudad de València. XVI Congreso Nacional De Arboriultura. Universidad Polytecnica de Valencia, Valencia, Spain, pp.1-4.

LABORDA R., GALAN-BlESA J., SANCHEZ-DOMINGO A., XAMANI P., ESTRUCH V.D., SElFA J., GUERRIERI E., RODRIGO E., 2015 - Preliminary study on the biology, natural enemies and chemical control of the invasive Macrohomotoma gladiata (Kuwayama) on urban Ficus microcarpa L. trees in Valencia (SE Spain). - Urban forestry \& urban greening, 14: 123-128. http://doi.org/10.1016/j.ufug.2014.12.007

Malumphy C., Guillem R., 2020 - First records of Cacopsylla fulguralis (Kuwayama) and Macrohomotoma gladiata Kuwayama in Gibraltar (Hemiptera: Psylloidea). - Entomologist's Monthly Magazine, 156 (1): 7-10. https://doi.org/10.31184/M00138908. 1561.4016 
MARTONI F., BROWn S.D.J., 2018 - An annotated checklist of the Cook Islands psyllids with keys to the species and two new records (Hemiptera, Psylloidea). ZooKeys, 811: 91-108. https://doi.org/10.3897/zookeys.811.28829

Mifsud D., CocQuempot C., MÜHLETHALER R., WILSON M., STREITO J.C., 2010 - Other Hemiptera Sternorrhyncha (Aleyrodidae, Phylloxeroidea, and Psylloidea) and Hemiptera Auchenorrhyncha Chapter 9.4. - BioRisk, 4(1): 511-552. https://doi.org/ 10.3897/biorisk.4.63

MifSUd D., PORCELLI F., 2012 - The psyllid Macrohomotoma gladiata Kuwayama, 1908 (Hemiptera: Psylloidea: Homotomidae): a Ficus pest recently introduced in the EPPO region. - Bulletin OEPP/EPPO Bulletin, 42 (1): 161-164. https://doi.org/10.1111/j.1365-2338.2012.02544.x

Mifsud D., Falzon A., Malumphy C., Lillo E., VOVLAS N., PORCELli F., 2012 - On some arthropods associated with Ficus species (Moraceae) in the Maltese Islands. - Bulletin of the Entomological Society of Malta, 5: 5-34.

NAVA D.E., TORRES M.L.G., RODRIGUES M.D.L., BENTO J.M.S., PARRA J.R.P., 2007 - Biology of Diaphorina citri (Hem., Psyllidae) on different hosts and at different temperatures. - Journal of Applied Entomology., 131(9-10): 709-715. https://doi.org/10.1111/j.1439-0418.2007.01230.x

Ouvrard D., 2021 - Psyl'list-The World Psylloidea Database. http://www.hemiptera-databases.com/ psyllist - 20 January 2021.

OUVRARD D., BURCKHARDT D., GREENWALT D., 2013 The oldest jumping plant-louse (Hemiptera: Sternorrhyncha) with comments on the classification and nomenclature of the Palaeogene Psylloidea. - Acta Musei Moraviae, Scientiae biologicae (Brno), 98(2): 21-33.

Ouvrard D., Chalise P., PerCy D., 2015 - Host-plant leaps versus host-plant shuffle: a global survey reveals contrasting patterns in an oligophagous insect group (Hemiptera, Psylloidea). - Systematics and Biodiversity, 13 (5): 434-454. https://doi.org/10.1080/14772000.2015.1046969
Pedata P.A., Burckhardt D., MANCINI D., 2012 - Severe infestations of the jumping plant-louse Macrohomotoma gladiata, a new species for Italy in urban $\mathrm{Fi}$ cus plantations. - Bulletin of Insectology, 65 (1): 9598.

PeriCART J., 1972 - Hémiptères. Anthocorides, Cimicidae et Microphysidae de l'Ouest Paléarctique. Faune de l'Europe et du Bassin Méditerranéen. 6ème ed. Volume 7, Masson et Cie éditeurs, Paris, 402 pp.

RADONJIC S., HRNCIC S., 2017 - First record of the alien psyllid Macrohomotoma gladiata (Hemiptera Psylloidea Homotomidae) in Montenegro. - Redia, 100: 77-80._http://dx.doi.org/10.19263/REDIA100.17.09

Roberti A., GERMAIN J.F., PIONNAT S., 2016 - Un Nouveau Ravageur Sur Ficus, Le Psylle Macrohomotoma gladiata Kuwayama. AFPP - 4 e Conférence Sur L'entretien Des Jardins, Espaces Végétalisés et Infrastructures Toulouse - 19 et 20 Octobre 2016, pp 125-132.

RUNG A., 2016 - A new pest of ficus in California: Macrohomotoma gladiata Kuwayama, 1908 (Hemiptera: Psylloidea: Homotomidae), new to North America. - Check List, 12(3): 1-5. https://doi.org/ 10.15560/12.3.1882

SÁNCHEZ I., 2012 - Primeras citas de Macrohomotoma gladiata (Hemiptera: Psylloidea: Homotomidae) en Andalucía (España). - Boletín de la Sociedad Entomológica Aragonesa, 50: 533-534.

SyRETT P., Fowler S. V., HARMAN H. M., HAYES L. M., Memmott J., SheAt J.J., 2007 - Establishment of Arytainilla spartiophila Förster (Hemiptera: Psyllidae), a new biological control agent for broom, Cytisus scoparius, in New Zealand. - New Zealand Entomologist, 30: 53-62. http://doi.org/ 10.1080/00779962.2007.9722151

YANG M.M., BURCKHARDT D., FANG S.J., 2009 - Families Calophyidae, Carsidaridae, Homotomidae and Phacopteronidae, with overview and keys to families and genera of Taiwanese Psylloidea (Insecta: Hemiptera). Vol. I, Psylloidea of Taiwan, Taichung, Taiwan: National Chung Hsing University, 96 pp. 